\title{
Escherichia coli $(E$. coli) as an indicator of fecal contamination in water: A review
}

\author{
Farhan Mohammad Khan ${ }^{1}$, Prof. Rajiv Gupta ${ }^{2}$ \\ 1 imfm2015@gmail.com, Research Scholar, Department of Civil Engineering, BITS Pilani, \\ Pilani, India. \\ 2 imfm93@gmail.com, Senior Professor, Department of Civil Engineering, BITS Pilani, Pilani, \\ India.
}

\begin{abstract}
Escherichia coli or E. coli is a member of the fecal coliform group and is a more specific indicator of fecal contamination than other fecal coliform species, its presence indicate possibly presence of harmful bacteria which will cause diseases and it also suggests the extent as well as the nature of the contaminants. E. coli bacteria able to survive in water for $4-12$ weeks and at present, it appears as an indicator to provide the accurate bacterial contamination of fecal matter in drinking water, because of the availability of simple, affordable, fast, sensitive and exact detection techniques. According to the laboratory experiment based techniques, 24 - 48 hours are required for the bacterial concentration to be reported. So, there is a necessity for continuous monitoring. Techniques for detection of many pathogenic bacterial strains are not yet available, sometimes days to weeks are required to get the results. To overcome the difficulties, expensive and time-consuming techniques are required to detect, count and identify the presence of specific bacterial strain. Public health relies on online monitoring of water quality that depends majorly on examination of fecal indicator bacteria, thus protection of health requires fecal pollution indicator so that it is not required to analyze drinking water to overcome the problems associated with waterborne diseases. This paper will brief the classification, sources, survival of E. coli bacteria and its correlation with basic water quality parameters in water sources.
\end{abstract}

Keywords: Escherichia coli,E. coli, indicator, fecal coliform bacteria, water, bacteriological analysis, FCB, classification.

\section{Introduction}

Water is more crucial in human life. An adequate, accessible and safe supply is needed to be available to the consumers. By improving access to clean drinking water, it will result in major benefits to the health. Efforts should be made to attain water quality as clean as possible for drinking [1]. In the present situation, people are struggling to obtain access to clean water. In general, the greatest infectious risks that are linked with ingestion of water is contaminated with human or animal feces. Some of the main health risks are caused by micro-organisms such as bacteria, pathogens, etc. because it may live, reproduce and disperse in water systems [2]. Approximately 1.7 billion children in developing countries under the age of five died due to diarrhea, mainly by drinking contaminated water that has been reported by the World Health Organization (WHO) in 2011. Besides, 525,000 children deaths a year in 2018 in world-wide because of the poor water quality, sanitation, and hygiene conditions, mainly through infectious diarrhea. In the world, 1.9 billion people use water which is faecally contaminated [3]. Annually about 37.7 million people in India are affected by waterborne diseases and 1.5 million children died by diarrhea. E. coli bacteria is present in the intestine of men and animals which released into the environment as a fecal material. Fecal matter is the main source of the disease-causing agents 
in water, fecal bacteria is widely used as an indicator of contamination that affect rivers, sea beaches, lakes, groundwater, surface water, recreational water. India has caused 10,738 deaths over the last five years since 2017. Uttar Pradesh has recorded the highest deaths due to diarrhea followed by Assam, West Bengal, Delhi and Madhya Pradesh [4].

In India, 19\% population wash hands with soap and water, which are in interaction with excreta, but $26 \%$ of people drink water which is infrequently contaminated with fecal bacteria [5]. 44\% of people have access to piped water, out of all only $32 \%$ of water has treated, so the large number of people do not have access of water within the house, it increases the possibilities of infection [6]. Water helps in maintaining the moisture of internal organs of the body, [7] It also maintains normal volume and uniformity of fluids such as blood and lymph [8], regulates body temperature and removes contaminants from the body through urine, sweat, and breathing [9] that are essential for regulating the functions of the skin [10]. It can lead to diseases such as diarrhea, kidney failure and can cause death if not treated immediately [23].

To facilitate abatement and control of water pollution, Microbiological water quality criteria was established for different water uses by WHO, EPA and IS 10500[24]. According to the standards, fecal coliform bacteria shall not be detectable in $100 \mathrm{ml}$ of water sample [44]. Microbiological water quality standards developed from those criteria established contaminant limits for several water uses. The bacteriological water quality standards are summarized in Table $1[24]$.

Table 1: Bacteriological Quality of Drinking Water [24]

\begin{tabular}{|l|l|lr|}
\hline S.No & Organisms & Requirements \\
\hline 1 & $\begin{array}{l}\text { Water intended for } \\
\text { drinking: } \\
\text { a) E. coli or } \\
\text { thermotolerant } \\
\text { coliform bacteria }\end{array}$ & $\begin{array}{l}\text { Shall not be } \\
\text { detectable in any } \\
100 \mathrm{ml} \text { sample }\end{array}$ \\
\hline 2 & $\begin{array}{l}\text { Treated water } \\
\text { entering the } \\
\text { distribution } \\
\text { system: } \\
\text { a) E. coli or } \\
\text { thermotolerant } \\
\text { coliform } \\
\text { bacteria } \\
\text { Total coliform } \\
\text { bacteria }\end{array}$ & $\begin{array}{l}\text { Shall not be } \\
\text { 10table in any }\end{array}$ \\
\hline 3 & $\begin{array}{l}\text { Treated water in } \\
\text { the distribution } \\
\text { system: }\end{array}$ & $\begin{array}{l}\text { Shall not be } \\
\text { detectable in any } \\
100 \mathrm{ml} \text { sample }\end{array}$ \\
\hline
\end{tabular}




\begin{tabular}{|l|l|l|}
\hline a) & $E . \quad$ coli or \\
& thermotolerant \\
& coliform \\
bacteria & \\
b) & $\begin{array}{l}\text { Total coliform } \\
\text { bacteria }\end{array}$ & \\
&
\end{tabular}

\section{Classification of Escherichia Coli}

Fecal coliform bacteria (FCB) include gram-negative, non-spore forming, rod-shaped pathogenic bacteria that produce gas upon fermentation in prescribed culture media within 48 hours at $35^{\circ} \mathrm{C}$. It can be classified into 3 groups which include commensal, diarrheagenic and extraintestinal. The fecal coliform bacteria include Citrobacter, Enterobacter, Hafnia, Klebsiella, and Escherichia in which Escherichia is the most common type which normally lives in the gastrointestinal tract of warm-blooded animals. Most strains of FCB, like the commensal groups, are harmless but there are some virulent types. The diarrheagenic strains can cause diseases such as diarrhea, hemorrhagic colitis, hemolytic uremic syndrome, inflammatory colitis, and dysentery. The extraintestinal strains can cause urinary tract infections, septicemia, and neonatal meningitis. FCB's are non-spore forming and rod-shaped with approximately $0.5 \mu \mathrm{m}$ in diameter and between 1.0 to $3.0 \mu \mathrm{m}$ in length. E. coli bacteria able to survive in water for $4-12$ weeks, depending on environmental conditions. Fecal coliform bacteria can be shown to live through various stresses and it is well documented that it can survive through temperatures well below freezing [11]. Various classification of coliform bacteria have been developed. In the earliest time, the MacConkay [12] in 1909 was identified 128 different types of coliform, in 1909 the Bergey and Deehan [13] was identified 256 types of coliform. But in the 1920s, variation of coliforms suggested indole and Voges-Proskauer reaction, that were amongst the more significant tests that have been used to determine the fecal contamination [14] The development was combined in the IMViC (Indole, Methyl red, Voges-Proskauer, and Citrate) tests in the variation of fecal coliforms, soil coliforms, and intermediates. Figure 1 [43] shows the classification of E. coli pathotypes based on growth supporting conditions.

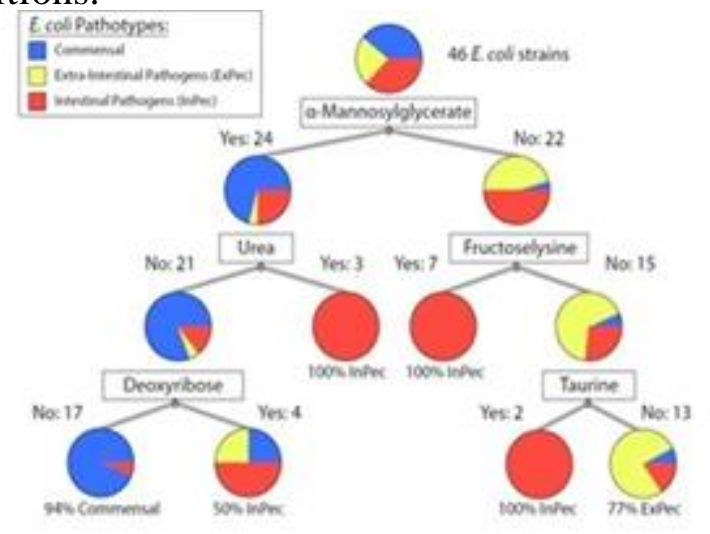

Figure 1: Classification of E. coli pathotypes based on growth supporting conditions [43]

\section{Sources of Escherichia coli}


The sources of Escherichia coli bacteria were normally linked with sewage discharges, divided into three general categories: human, animal and plant. Human sources include failing septic systems, municipal landfills and land application of wastewater sludge. Fecal coliform bacteria also enters from a variety of animal sources, including domestic pets, wildlife, livestock, land application of manure, pasture areas and feedlots. Drinking water comes from surface and groundwater sources. Surface water sources consist of rivers, reservoirs, and lakes where groundwater was pumped from wells or boreholes, then it was drilled into aquifers. Due to damaged sanitation and dwindling resources that makes the availability of safe water almost inaccessible because of the bacterial and chemical contaminations [15]. Contamination results due to water draining out from the agricultural land or directly from livestock and birds as well as from leakage of sewage, overflow of sewer caused by storm events and release of contaminated water into the receiving water bodies $[40,41]$. Sewage treatment plants (STP) was one of the source of pathogenic $E$. coli bacteria which isolated into the river systems [38, 39]. Even low levels of contact in rivers [37] or beaches [46] with contaminated water were important and results in the occurrence of gastrointestinal disorders. The amount of ingested water was most significant when determining the risk of various activities i.e., swimming, boating, etc. [16]. Even though fecal coliform bacteria do not commonly cause serious diseases, but we're used to indicate the presence of pathogenic bacteria and viruses [25].

\section{E. coli as an indicator of fecal contamination:}

The presence of fecal indicator organism or fecal indicator bacteria (FIB) shows that the contamination have occurred, it also suggests the extent and nature of the contaminants. FIB does not cause diseases while associated with pathogens but, E. coli as an FIB proved to be a microorganism whose presence is an indication of fecal contamination. E. coli bacteria is able to survive in water for 4-12 weeks and at present, it appears to provide the accurate bacterial contamination indicator of fecal contamination in drinking water because of the availability of simple, affordable, fast, sensitive and exact detection methods. Figure 2 [42] shows the approach for monitoring of water contamination. Total coliform (TC) is not regarded as an indicator organism. The ideal FIB have the following characteristics [45]:

- FIB should be present when pathogenic strains are present.

- FIB should be absent where pathogenic strains are absent.

- Number of counts of FIB correlates to the extent of pollution.

- Number of counts of FIB should be more than that of pathogenic strains.

- There should be no furthermore growth of FIB in water.

- There should be greater or equal survival time of FIB than pathogenic strains.

- FIB should be easily and quickly detected by laboratory tests.

- FIB should have constant biochemical and identifying features.FIB should be harmless to humans. 


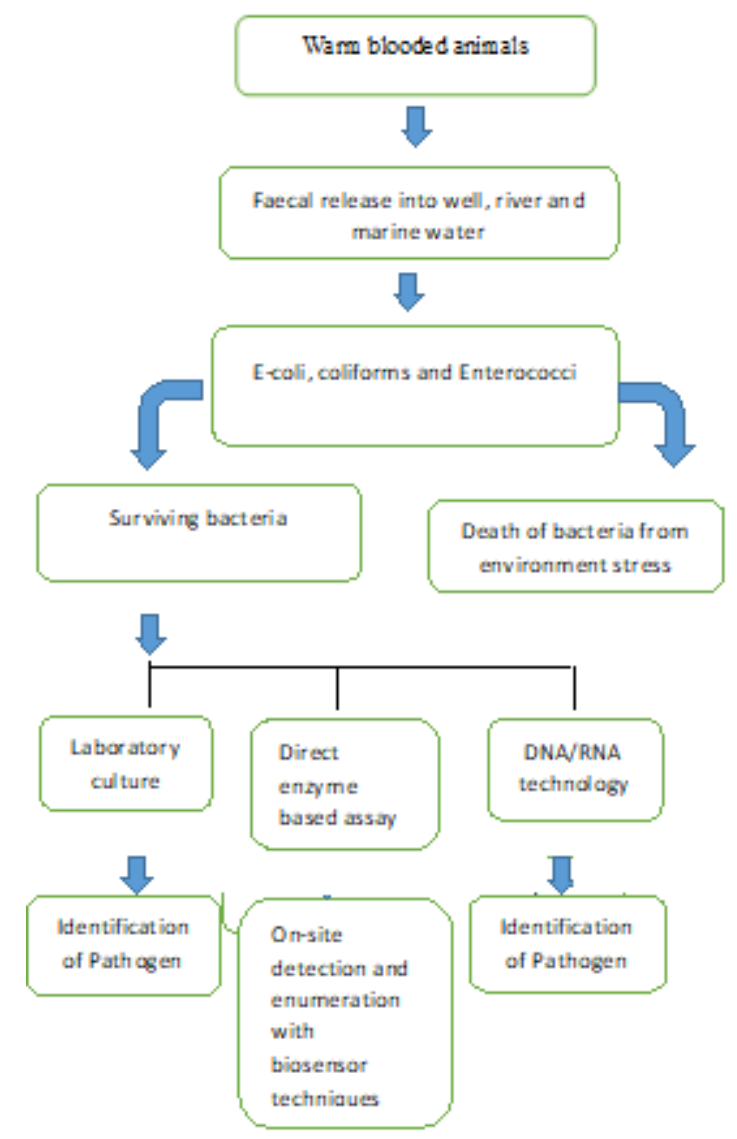

Figure 2: Approach for monitoring of water contamination [42]

\section{Correlations between water quality parameters and $E$. coli:}

Survival of bacteria in surface water usually increases with the decrease in temperature. Other factors that have an impact on survival include dissolved organic carbon concentration, sunlight intensity [17]. In a relative study on the growth of 10 different coliform bacterial species that includes $E$. coli inoculated in sterilized river water with different concentrations of dissolved organic carbon, Boualam et al. [19] found that only Citrobacter freundii, Klebsiella pneumonia and Enterobacter cloacae subsp. cloacae was remained cultivable after 96 hours of incubation.

In a previous study by using the same bacterial strain and medium, Boualam et al. [20] found that after 28 days, only Citrobacter freundii and Enterobacter cloacae subsp. cloacae have been found living. Baudišová [21] reported a relative study on the survival of fecal coliforms, total coliforms and $E$. coli in contaminated and uncontaminated river water and found that in contaminated water conditions, all bacteria lived for several months but in uncontaminated water conditions, the removal amount of all bacteria was significantly faster. Total coliforms lasted the longest and E. coli the shortest. Table 2 [17] shows the reduction times for fecal bacteria in surface water.

Table 2: Reduction times for fecal bacteria in surface water [17] 


\begin{tabular}{|l|l|}
\hline $\begin{array}{l}\text { Bacterial } \\
\text { group }\end{array}$ & \begin{tabular}{l} 
Time for $\begin{array}{r}\mathbf{5 0 \%} \\
\text { reduction } \\
\text { concentration }\end{array}$ \\
\hline $\begin{array}{l}\text { Total } \\
\text { coliforms }\end{array}$
\end{tabular} \\
\hline E. coli & 0.9 \\
\hline Enterococci & $0.9-4$ \\
\hline $\begin{array}{l}\text { Clostridium } \\
\text { perfringens }\end{array}$ & $60->300$ \\
\hline Salmonella & $0.1-0.67$ \\
\hline Shigella & 1 \\
\hline
\end{tabular}

The survival of bacterial strains in groundwater was affected by some factors that was linked with soil. Bacteria had to percolate through the soil to reach the groundwater that was enhanced by low temperature, high soil humidity, neutral or alkaline soil $\mathrm{pH}$ and the presence of organic carbon [17]. In a study reported by Doran and Linn [22] in eastern Nebraska for three years, runoff from a cow-calf pasture was observed. Fecal streptococci counts were higher in runoff from the ungrazed area that revealed the contributions from wildlife. Table 3 [17] shows disappearance rates of fecal bacteria in groundwater sources. The pollutants carried in runoff originates from urban and sub-urban non-point sources [18].

Table 3: Disappearance rates of fecal bacteria in groundwater sources [17]

\begin{tabular}{|l|l|}
\hline Bacterial group & $\begin{array}{l}\text { Disappearance rate } \\
\text { (per day) }\end{array}$ \\
\hline E. coli & $0.063-0.36$ \\
\hline Faecal streptococci & $0.03-0.24$ \\
\hline $\begin{array}{l}\text { Clostridium } \\
\text { bifermentans } \\
\text { spores }\end{array}$ & 0.00 \\
\hline $\begin{array}{l}\text { Salmonella subsp. } \\
\text { enterica serovar } \\
\text { enterica } \\
\text { Typhimurium }\end{array}$ & $0.23-0.22$ \\
\hline
\end{tabular}

Many studies have been reported significantly of correlations between various water quality parameters and fecal coliform bacteria. Kim C et. al [29] studied the properties of electrolyzed oxidizing water for the inactivation of bacteria and to evaluate chemically modified solutions in killing Escherichia coli O157: H7, having properties similar to electrolyzed oxidizing water. It was observed that inactivation of $E$. coli occurred within 30 seconds after the application of electrolyzed oxidizing water and solutions containing $1 \%$ bromine and chlorine after that buffer was added to neutralize chlorine. Residual chlorine was added to reduce oxidation-reduction potential (ORP) readings. Iron was found to be the only solution that was effective in the inactivation of $E$. coli O157: H7 and having high ORP readings then residual. The study 
recommended that it was possible to simulate electrolyzed oxidizing water by chemically modifying deionized water, whereas ORP of the solution was the crucial factor affecting bacterial inactivation. Hughes [28] studied the impacts of temperature, water salinity, solar radiation, sea ice conditions, and fecal contamination on the fecal coliform count around Rothera Point, Adelaide Island, and Antarctic Peninsula during February 1999 to September 1999. In summeri.e. February, the presumptive fecal coliform counts were low due to the effects of solar radiation and high station population. Daily solar radiation amount was high and the presumptive fecal coliform counts were low. In winter i.e. April, fecal coliform counts were high due to increased fecal matter by migrant wildlife and the solar radiation dropped by $95 \%$. By late winter i.e. September near the station sewage outfall, fecal coliform counts were high but the fecal coliform counts in North Cove were high as compared to February. It was observed that solar radiation was the leading factor in determining fecal coliform counts in the sea. Water depth, temperature, and salinity also affect fecal bacterial viability by increasing cell inactivation. Park H et. al [26] explained the effects of $\mathrm{pH}$ and chlorine on Escherichia coli O157: $\mathrm{H} 7$ and Listeria monocytogenes. The effect of $\mathrm{pH}$ was examined at $\mathrm{pH}$ 3.0, 5.0 and 7.0 and the residual chlorine concentration of electrolyzed water ranged from 0.1 to $5.0 \mathrm{mg} / \mathrm{l}$. The bactericidal activity increased with the increase in residual chlorine concentration and complete inactivation of the bacteria was attained at residual chlorine levels equal to or higher than $1.0 \mathrm{mg} / \mathrm{l}$. The results revealed that both Escherichia coli and Listeria monocytogenes were sensitive to residual chlorine and chlorine level of electrolyzed water, and the bactericidal activity of electrolyzed water increased with decrease in $\mathrm{pH}$ of water for both Escherichia coli and Listeria monocytogenes. The study recommends that with residual chlorine greater than $2 \mathrm{mg} / \mathrm{l}$, electrolyzed water can be applied in a $\mathrm{pH}$ range between 2.6 and 7.0 for attaining complete inactivation of Escherichia coli and Listeria monocytogenes. Roslev P et. al [30] studied the effect of oxygen on the survival of fecal coliform bacteria in non-disinfected drinking water. Escherichia coli ATCC 25922 showed a reduced and biphasic decrease in growth. Also the survival of fecal enterococci, somatic coliphages and coliforms appeared to be decreased in aerobic conditions and oxygen was the major factor for the growth of $E$. coli in non-disinfected drinking water. Juhna T et. al [34] studied the effects of the addition of phosphorus on the survival of $E$. coli bacteria. Higher phosphorus concentrations extended the survival of culturable $E$. coli in biofilms and water. The study showed that higher phosphorus concentration in water increased the cultivability of E. coli in biofilms of water distribution systems. Ellie L.B et. al [33] proved a direct connection with an $\mathrm{R}^{2}$ value ranging from 0.6 to 0.8 . From the six sites, turbidity ranged from 5.7 to 120 NTU with a mean of 12-17 NTU. Fecal coliform bacteria ranged from 20 to 25000 $\mathrm{col} / 100 \mathrm{~mL}$ with a geometric mean of 180 to $340 \mathrm{col} / 100 \mathrm{~mL}$. Direct relation was observed between fecal coliform and turbidity. As field parameters were taken at the site, increased turbidity standards can be used to predict increased levels of fecal coliform bacteria. Kreske A.C et. al [27] explained the ability of Escherichia coli O157: $\mathrm{H} 7$ to grow in acidified vegetable products and the survival in acidified vegetable products at $\mathrm{pH} 3.2$ and 3.7, under different dissolved oxygen contents and a range of ionic strengths 0.086 to 1.14 . The study revealed that $E$. coli lasted significantly better in acid solutions under anaerobic conditions than under aerobic conditions. For all the acid solutions tested in the absence of oxygen, E. coli strain reduced only by $1.55 \log$ $\mathrm{CFU} / \mathrm{ml}$. Kalantari N et. al [35] studied the effects of iron, cadmium, chromium on the growth of E. coli bacteria. In the series of experiments, $E$. coli cultured in a nutrient broth added with $\mathrm{Fe}+2$, $\mathrm{Fe}+3, \mathrm{Cr}+3, \mathrm{Cd}+2$, at $37^{\circ} \mathrm{C}$ for 5 hours. Bacterial growth was measured after every half an hour using a spectrophotometer. Results showed that bacterial growth reduced in presence of $1 \mathrm{mM} / \mathrm{L}$ concentration of $\mathrm{Fe}+3$ and $0.5 \mathrm{mM} / \mathrm{L} \mathrm{Fe}+2$, but the growth was completely affected by $1 \mathrm{mM} / \mathrm{L}$ 
concentration of iron (II). Chromium also showed effects on the growth, whereas cadmium exhibited poisonous effects. $\mathrm{Cr}+3$ and $\mathrm{Cd}+$ found to have antagonism effects with iron on the growth of bacteria. Than A.A [32] reported the growth of Escherichia in water under different temperatures ranges from $0-70^{\circ} \mathrm{C}$ at the laboratory of microbiology in the Department of Zoology, University of Yangon. The bacteria cell growths were recorded as $1.28 \times 108 \mathrm{CFU} / \mathrm{ml}$ at $20^{\circ} \mathrm{C}$, $3.25 \times 108 \mathrm{CFU}$ at $30^{\circ} \mathrm{C}$ and $4.85 \times 108 \mathrm{CFU} / \mathrm{ml}$ at $40^{\circ} \mathrm{C}$ on nutrient agar. The bacterial count at $37^{\circ} \mathrm{C}$ was $4.98 \times 108 \mathrm{CFU} / \mathrm{ml}$. Bacterial colonies formation were not observed under the temperature of $50^{\circ} \mathrm{C}, 60^{\circ} \mathrm{C}$, and $70^{\circ} \mathrm{C}$. The recorded data revealed that E. coli was found to grow at temperatures between $20^{\circ} \mathrm{C}$ and $40^{\circ} \mathrm{C}$. Sinaga D.M et. al [36] observed the counts of fecal coliform bacteria in well water sources and the factors that were associated with the growth of bacteria. Water samples were collected from 5 wells to study the concentrations of total fecal coliform bacteria, mercury, inorganic nitrogen compounds, total phosphorus, dissolved oxygen, $\mathrm{pH}$, and salinity. Results showed that the drinking water resources at the Sekotong regency were contaminated by coliform bacteria and mercury, also mercury and salinity showed inverse correlation with the growth of fecal coliform. Whereas $\mathrm{pH}$ supports the fecal coliform survival at the range of $6.05-6.50$, but no relationship was found between total phosphorus and inorganic nitrogen compounds to the growth of fecal coliform bacteria. However, the growth of fecal coliform bacteria was positively related to the concentration of phosphorus in water but negatively related to nitrate concentration. Kim $\mathrm{C}$ et. al [31] observed the growth features of foodborne pathogens in a laboratory medium incubated at a range of temperatures 25 to $45^{\circ} \mathrm{C}$ and $\mathrm{pH}$ levels 3 to 10 . Results showed that the densities of all species were limited to $\leq 3 \log \mathrm{CFU} / \mathrm{ml}$ when subjected to $\mathrm{pH} 3$ and 4 at any tested temperature, and all $\mathrm{pH}$ at $45^{\circ} \mathrm{C}$. The results indicated that at $\mathrm{pH}$ 6, growth rates of E. coli and Salmonella were approximately three and half to four times faster than that of Listeria and at $\mathrm{pH} 7$, the growing rates of Bacillus, E. coli and Salmonella were significantly higher than those of Listeria and Staphylococcus. At $\mathrm{pH} \mathrm{8,} \mathrm{the} \mathrm{growth} \mathrm{rate} \mathrm{of} \mathrm{Bacillus} \mathrm{was} \mathrm{the} \mathrm{highest} \mathrm{as} \mathrm{compare} \mathrm{to} \mathrm{Salmonella,}$ E. coli, Listeria and Staphylococcus. E. coli and Salmonella were less susceptible than other bacterial species to acidic environments at $\mathrm{pH} 5-6$, while Bacillus was the least susceptible to alkaline environments at $\mathrm{pH} 8-9$.

\section{Conclusion}

Measuring bacterial contamination in water resources has become a critical issue to indicate fecal contamination from human and animal. E. coli appears to be the best and accurate indicator of fecal contamination in drinking. Sensitive and continuous online monitoring for early warning of $E$. coli contamination is needed to minimize the adverse effects on human health.

\section{References:}

1. WHO (2011). Guidelines for Drinking-water Quality. 4th ed.; WHO: Geneva, Switzerland 2. Payus C (2018). Faecal Bacteria Contaminations in Untreated Drinking Water Groundwater Well and Hill Water from Rural Community Areas, 215-218.

3. Diarrhoeal disease, World Health Organisation Media (2017). Available Online at http://www.who.int/mediacentre/factsheets/fs330/en

4. $\quad$ CBHI National Health Profile (2018), 13th Issue.

5. World Health Statistics (2017). WHO.

6. India Water Portal (2019) Available Online at https://www.indiawaterportal.org/

7. Gerald P. Water science. University of Washington. Available Online athttp://faculty.washington.edu/ghp/researcthemes/water-science. Accessed (February 2011). 
8. Ehlers E, Krafft T (2001). Understanding the earth system: compartments, processes, and interactions, 116.

9. Earthscan, and Colombo (2007) Comprehensive Assessment of Water Management in Agriculture. Water for food, water for life: a comprehensive assessment of water management in agriculture.

10. Burton GA, Gunnison D, Lanza JR (1987). Survival of pathogenic bacteria in various freshwater sediments. Applied and Environmental Microbiology. 53:633-8.

11. Nevers M.B (2011). Modeling fate and transport of fecal bacteria in surface water. Applied and Industrial Microbiology; Environmental Microbiology.

12. MacConkey AT (1909). Further observations on the differentiation of lactose-fermenting bacilli with special reference to those of intestinal origin. Journal of Hydrology, 86.

13. Bergey DH, Deehan SJ (1908). The colon-aerogenes group of bacteria. Journal of Medical Research, 175.

14. Hendricks CW (1978). Exceptions to the coliform and the fecal coliform tests. In: Berg G,ed. Indicators of viruses in water and food. Ann Arbor Science publishers, 99-145.

15. Cabral J.P.S (2010). Water Microbiology. Bacterial Pathogens and Water. International Journal of Environmental Research and Public Health, 3657-3703.

16. Rompré A (2002). Detection and enumeration of coliforms in drinking water: current methods and emerging approaches. Journal of microbiological methods, 31-54.

17. Medema, G.J; Shaw, S.; Waite, M.; Snozzi, M.; Morreau, A.; Grabow, W (2003). Catchment characteristics and source water quality. In Assessing Microbial Safety of Drinking Water. Improving Approaches and Method; WHO \& OECD, IWA Publishing, 111-158.

18. EPA (2009). Source Water Protection Practices Bulletin. Managing Stormwater Runoff to Prevent Contamination of Drinking Water; Office of Water (4606); United States Environmental Protection Agency (EPA): Washington, DC, USA.

19. Boualam M, Mathieu L, Fass S, Cavard J, Gatel D (2002). Relationship between Coliform Culturability and Organic Matter in Low Nutritive Waters. Water Resources, 2618-2626.

20. Boualam M, Fass S, Saby S, Lahoussine V, Cavard J, Gatel D, Mathieu L (2003). Organic Matter Quality and Survival of Coliforms in Low-Nutrient Waters. Journal AWWA, 119-126.

21. Baudišová D (1997). Evaluation of Escherichia coli as the Main Indicator of Faecal Pollution. Water Science Technology, 333-336.

22. Doran J.W, Linn D.M (1979). Bacteriological Quality of Runoff Water from Pasteureland. Applied Environmental Microbiology, 985-991.

23. David M.M (2011). Development of Regression-Based Models to Predict Fecal Bacteria Numbers at Select Sites within the Illinois River Watershed, Arkansas and Oklahoma, USA. Water Air and Soil Pollution, 525-547.

24. Indian standard drinking water specification (Second Revision), IS 10500:2012.

25. Dorevitch S, Pratap P, Wroblewski M, Hryhorczuk DO, Li H, Liu LC, Scheff PA (2012). Health risks of limited-contact water recreation. Environmental Health Perspectives, 192-197.

26. Park H (2004). Effects of chlorine and $\mathrm{pH}$ on efficacy of electrolyzed water for inactivating Escherichia coli O157:H7 and Listeria monocytogenes. International Journal of Food Microbiology, 13-18.

27. Kreske A.C (2008). Effects of pH, Dissolved Oxygen, and Ionic Strength on the Survival of Escherichia coli O157:H7 in Organic Acid Solutions. Journal of Food Protection, 71(12), 2404-2409. 
28. Hughes K.A (2003). Influence of Seasonal Environmental Variables on the Distribution of Presumptive Fecal Coliforms around an Antarctic Research Station. Applied and Environmental Microbiology, 4884-4891.

29. Kim C. (2000). Roles of Oxidation-Reduction Potential in Electrolyzed Oxidizing and Chemically Modified Water for the Inactivation of Food-Related Pathogens. Journal of Food Protection, 63(1), 19-24.

30. Roslev P. (2004). Effect of oxygen on survival of faecal pollution indicators in drinking water. Journal of Applied Microbiology, 938-945.

31. Kim C (2018). Influence of PH and Temperature on Growth Characteristics of Leading Foodborne Pathogens in a Laboratory Medium and Select Food Beverages. Austin Food Science, $3(1)$.

32. Than A.A (2011). Effect of Temperatures on the Growth of Escherichia coli from Water. Universities Research Journal, 4(2).

33. Ellie L.B (2007). The Correlation of Fecal Coliform and Turbidity of the Little Tallapoosa River in the West Georgia Region. GSA Denver Annual Meeting, 28-31 October 2007.

34. Juhna T (2007). Effect of Phosphorus on Survival of Escherichia coli in Drinking Water Biofilms. Applied and Environmental Microbiology, 3755-3758.

35. Kalantari N (2008). Evaluation of toxicity of heavy metals for escherichia coli growth. Iranian Journal of Environmental Health Science \& Engineering, 5(3), 173-178.

36. Sinaga D.M (2016). Fecal coliform bacteria and factors related to its growth at the sekotong shallow wells, west nusa tenggara, Indonesia. Public Health of Indonesia, 47-54.

37. Madoux-Humery A-S, Dorner S, Sauve S, Aboulfadl K, Galarneau M, Servais P, Prevost M (2016). The effects of combined sewer overflow on riverine sources of drinking water. Water Resources, 218-227.

38. Eichmiller JJ, Hicks R, Sadowsky MJ. "Distribution of genetic markers of fecal pollution on a freshwater sandy shoreline in proximity to wastewater effluent", Environ. Sci.Technol. 2013, 47, 7, 3395-3402.

39. Anastasi EM, Matthews B, Stratton HM, Katouli M (2012). Pathogenic Escherichia coli found in sewage treatment plants and environmental waters. Applied Environmental Microbiology, 78(16), 5536-5541.

40. Cornejova T, Venglovsky J, Gregova G, Kmetova M, Kmet V (2015). Extended spectrum betalactamases in Escherichia coli from municipal wastewater. Annals of Agricultural and Environmental Medicine, 22(3), 447-450.

41. Pandey PK, Kass PH, Supir ML, Biswas S, Singh VP. "Contamination of water resources by pathogenic bacteria", AMB Express 2014, 4:51.

42. Price G.R (2017). E-coli as an Indicator of Contamination and Health Risk in Environmental Waters. Recent Advances on Physiology, Pathogenesis and Biotechnological Applications, 125-139.

43. Monk JM (2017). Genome-scale metabolic reconstructions of multiple Escherichia coli strains highlight strain-specific adaptations to nutritional environments. Proceedings of the National Academy of Sciences of the United States of America.

44. Doran J.W, Linn D.M (1979). Bacteriological Quality of Runoff Water from Pasteureland. Applied Environmental Microbiology, 985-991.

45. Tallon P (2005). Microbial indicators of faecal contamination in water: a current perspective. Water, Air, and Soil Pollution, 139-166. 
46. Boehm A, Sassoubre LM (2014). Enterococci as indicators of environmental contamination. Commensals to leading to causes of drug resistant infections. 